\title{
BADANIA UKSZTAŁTOWANIA I SPRAWNOŚCI SKRZYŻOWAŃ Z SYGNALIZACJĄ ŚWIETLNĄ
}

\begin{abstract}
Badania prowadzone na miejskich i zlokalizowanych poza terenem zabudowy skrzyżowaniach z sygnalizacją świetlną wykazały specyfikę ukształtowania, obciążenia ruchem, w pewnym zakresie również sterowania jak i funkcjonowania miejskich i zamiejskich skrzyżowań. Skrzyżowania z sygnalizacją świetlną zlokalizowane poza terenem zabudowy mają wiele wyróżniających je cech zarówno w zakresie geometrii, organizacji ruchu jak i sterowania. Jest to konsekwencją wyższych dopuszczalnych prędkości, specyficznych charakterystyk ruchu jak też zagospodarowania otoczenia. Badania identyfikacyjne umożliwiły wyspecyfikowanie zbioru cech charakterystycznych dla takich skrzyżowań. Ponadto prowadzona była analiza odstępów czasu na linii zatrzymań między pojazdami z kolejki (samochody osobowe), która umożliwiła określenie natężeń nasycenia w poszczególnych cyklach sygnalizacyjnych. Scharakteryzowano statystycznie ich zmienność oraz określono różnice pomiędzy skrzyżowaniami miejskimi i zamiejskimi. Natężenia nasycenia na wlotach skrzyżowań zamiejskich przyjmują znacznie niższe wartości, powodując przy zbliżonych natężeniach ruchu znacznie gorsze warunki ruchu niż na skrzyżowaniach miejskich. Wykazano wpływ na natężenie nasycenia liczby i lokalizacji pasów, z których korzystają pojazdy relacji na wprost, intensywności zagospodarowania otoczenia skrzyżowań zamiejskich oraz warunków pogodowych. Opracowano regresyjne modele estymacji natężeń nasycenia. Wyniki badań wskazują potrzebę podjęcia prac umożliwiających aktualizację i uzupełnienie obecnych wytycznych projektowania skrzyżowań i rozporządzeń dotyczących sygnalizacji świetlnej na skrzyżowaniach oraz weryfikacji metody analizy przepustowości i warunków ruchu na skrzyżowaniach z sygnalizacją.
\end{abstract}

Słowa kluczowe: skrzyżowanie z sygnalizacją, cechy skrzyżowania, sprawność skrzyżowania

\section{Wprowadzenie}

Przebudowa i instalowanie sygnalizacji świetlnej na zlokalizowanych poza terenem zabudowy skrzyżowaniach ma na celu poprawę bezpieczeństwa ruchu przy równoczesnym zapewnieniu właściwej sprawności obiektu. Poprawa bezpie-

\footnotetext{
${ }^{1}$ Autor do korespondencji/corresponding author: Janusz Chodur, Politechnika Krakowska, Instytut Inżynierii Drogowej i Kolejowej, ul. Warszawska 24, 31-155 Kraków, 126282355, jchodur@pk.edu.pl

${ }^{2}$ Krzysztof Ostrowski, Politechnika Krakowska, Instytut Inżynierii Drogowej i Kolejowej, ul. Warszawska 24, 31-155 Kraków, 126282539, kostrowski@pk.edu.pl
} 
czeństwa ruchu po wprowadzeniu sygnalizacji świetlnej determinowana jest jednak spełnieniem wielu warunków w zakresie geometrycznego ukształtowania skrzyżowania, organizacji ruchu i sposobu sterowania oraz spójności tych elementów rozwiązania. Coraz częstsze stosowanie w Polsce sygnalizacji świetlnej do regulacji ruchu na skrzyżowaniach zamiejskich skłoniło autorów do realizacji w latach 2008 - 2012 badań empirycznych sprawności skrzyżowań zarówno miejskich jak i zamiejskich oraz potencjalnych czynników determinujących ich funkcjonowanie [8]. Badaniami objęto cechy geometryczne skrzyżowań jak również cechy ruchu pojazdów i pieszych.

Skrzyżowania z sygnalizacją świetlną zlokalizowane na drogach poza terenem zabudowy mają swoją specyfikę, która determinowana jest w dużej mierze przez:

- duże prędkości ruchu na drodze głównej, znacznie przekraczające prędkość dopuszczalną na terenie zabudowy,

- dużą dysproporcję obciążenia kierunku głównego (zwykle drogi krajowej) i drogi podporządkowanej,

- nieznaczny ruch pieszych, najczęściej związany z przystankami komunikacji zbiorowej wymagający zapewnienia długości fazy umożliwiającej bezpieczne przejście przez drogę z pierwszeństwem przejazdu, która ma znaczący udział w cyklu sygnalizacyjnym nie zawsze adekwatny do natężeń ruchu na drodze bocznej,

- znaczny udział pojazdów ciężkich w potokach ruchu na drodze głównej, w tym pojazdów członowych,

- brak intensywnego zagospodarowania otaczającego skrzyżowanie i większa dostępność terenu, co pozwala na dopasowanie geometrii wlotów do potrzeb ruchowych i sterowania.

Podobne uwarunkowania wpływają również na kształtowanie i funkcjonowanie skrzyżowań zlokalizowanych $\mathrm{w}$ obrębie miast $\mathrm{w}$ arteriach o prędkości podwyższonej w stosunku do dopuszczalnej w terenie zabudowy i cechujących się także niewielkim ruchem pieszym (arterie wlotowe).

Do sterowania ruchem na takich skrzyżowaniach wykorzystuje się zaawansowane sygnalizacje akomodacyjne lub acykliczne z detekcją przy pomocy czujników indukcyjnych lub wideodetektorów. Sygnalizacja powinna poprawić bezpieczeństwo ruchu na skrzyżowaniu, a więc oprócz właściwego rozdzielenia w czasie kolizyjnych strumieni ruchu, powinna również zapewnić ochronę strefy dylematu na dojeździe do skrzyżowania, której długość zwiększa się ze wzrostem prędkości ruchu na wlotach skrzyżowania, a może skutkować wjazdami na skrzyżowanie pojazdów na sygnale czerwonym. Bezpieczeństwo ruchu i warunki ruchu pojazdów z kierunków bocznych najczęściej poprawiają się po wprowadzeniu sterowania ruchem za pomocą sygnalizacji, ale powstają nowe, nie do końca poznane zagrożenia związane z przejazdem z dużą prędkością pojazdów z kierunku głównego.

Ze względu na złożoność sytuacji ruchowej istotne jest umiejętne przygotowanie algorytmu sterowania preferującego płynność ruchu na drodze nadrzędnej (która często jest drogą krajową lub wojewódzką) i zapewniającego przepustowość dla potoków z wlotów drogi bocznej. Podejście projektowe powinno obejmować proces optymalizacji, którego efektem końcowym jest wybór najlepszego 
rozwiązania z punktu widzenia potrzeb bezpieczeństwa i uczestników ruchu drogowego, którzy oczekują od skrzyżowania utrzymania wysokich standardów obsługi. Istotne jest zatem w ocenie sprawności skrzyżowań poprawne szacowanie przepustowości wlotów, a jego podstawę w przypadku skrzyżowań z sygnalizacją stanowi właściwe określenie natężeń nasycenia. Charakterystykę tej ważnej cechy, a zwłaszcza jest zróżnicowanie w zależności od lokalizacji skrzyżowania i warunków pogodowych przedstawiono w niniejszym artykule.

Stosunkowo do niedawna skrzyżowania z sygnalizacją świetlną stosowane były wyłącznie w miastach. Dotyczyło to nie tylko Polski, ale i wielu innych wysoko rozwiniętych państw. Głównie do tego stanu dostosowane są krajowe przepisy oraz procedury projektowe $[21,27]$. Dla skrzyżowań drogowych zlokalizowanych poza terenem zabudowy przewidziane są rozwiązania $\mathrm{z}$ ruchem regulowanym za pomocą znaków drogowych. Rozwiązania te tak w zakresie geometrii jak i organizacji ruchu różnią się istotnie od skrzyżowań z sygnalizacją. W literaturze krajowej brak jest specjalistycznej wiedzy w tym zakresie. Brak jest również ważnych uregulowań w zakresie sterowania. Pewne zasady i wzorce rozwiązań skrzyżowań, w tym z sygnalizacją można czerpać z wytycznych niemieckich $[22,23$, 24] oraz amerykańskich $[1,26]$. W literaturze zagranicznej, głównie z USA, pojawiły się w ostatnich latach wyniki badań bezpieczeństwa ruchu na skrzyżowaniach z wysokimi prędkościami pojazdów oraz wpływu pewnych cech sterowania i detekcji ruchu na bezpieczeństwo jego przebiegu na skrzyżowaniu [9]. Często badane są wjazdy pojazdów na sygnale czerwonym i analizowane możliwości rozwiązań z zakresu nadzoru ruchu dla redukcji liczby tych niebezpiecznych wjazdów [19]. Wypracowana w wyniku tych badań metodyka działań może być adaptowana do warunków polskich, lecz należy zidentyfikować specyfikę zachowań lokalnych kierowców i dostosować parametry modeli sterowania.

\section{Specyfika geometrii skrzyżowań}

Skrzyżowania drogowe zlokalizowane na terenach zabudowy i poza nimi projektuje się nieco inaczej, kładąc większy nacisk na względy dynamiki ruchu w przypadku skrzyżowań poza terenem zabudowy, a na sprawność obsługi różnych uczestników ruchu w przypadku skrzyżowań na terenie zabudowy. Zakres rozbudowy skrzyżowania zależy od klas i funkcji krzyżujących się dróg, prędkości miarodajnej, natężeń ruchu oraz przyjętego sposobu sterowania ruchem. W przypadku skrzyżowań z sygnalizacją świetlną istnieje ścisły związek pomiędzy rozwiązaniem geometrycznym skrzyżowania i sterowaniem ruchem za pomocą sygnalizacji świetlnej. W projektowaniu takich skrzyżowań należy rozróżnić dwa przypadki; projektowanie skrzyżowania z sygnalizacją oraz projektowanie sygnalizacji na istniejącym skrzyżowaniu, często bez zmiany jego geometrii. W pierwszym przypadku celowe i możliwe jest wzajemne dostosowanie cech geometrii skrzyżowania, organizacji ruchu oraz rozwiązania sygnalizacji dla uzyskania optymalnego efektu z uwzględnieniem różnych kryteriów. W drugim przypadku projektowanie przebiega z ograniczeniami narzuconymi przez istniejące rozwiązanie skrzyżowa- 
nia. Możliwy jest też wariant pośredni, w którym wprowadza się częściowe (ograniczone) dostosowanie geometrii skrzyżowania do potrzeb sterowania.

Podstawowe, wynikające $\mathrm{z}$ przepisów $[8,21,27]$ różnice projektowe w zakresie rozwiązań skrzyżowań z sygnalizacją na terenach zabudowy i poza nimi zestawiono w tab. 1.

Tabela 1. Porównanie wymagań i parametrów projektowych skrzyżowań z sygnalizacją na i poza terenem zabudowy, na podstawie [8,21,27]

Table 1. Comparison of requirements and design parameters for signalised intersections in rural areas and in urban areas, based on $[8,21,27]$

\begin{tabular}{|c|c|c|c|}
\hline \multirow[b]{2}{*}{$\begin{array}{l}\text { Wymagania } \\
\text { i parametry projektowe }\end{array}$} & \multicolumn{2}{|c|}{ Skrzyżowania z sygnalizacją } & \multirow[b]{2}{*}{ Komentarz } \\
\hline & $\begin{array}{c}\text { teren } \\
\text { zabudowy }\end{array}$ & $\begin{array}{c}\text { poza terenem } \\
\text { zabudowy }\end{array}$ & \\
\hline $\begin{array}{l}\text { Prędkość miarodajna } \\
{[\mathrm{km} / \mathrm{h}]}\end{array}$ & $\begin{array}{c}\text { mniejsza } \\
v_{m}=40-90\end{array}$ & $\begin{array}{c}\text { więkssza } \\
v_{m}=60-100\end{array}$ & $\begin{array}{l}\text { Redukcja prędkości stosowana jest } \\
\text { poza terenem zabudowy (najczęściej } \\
\text { do } 70 \mathrm{~km} / \mathrm{h} \text { ) }\end{array}$ \\
\hline $\begin{array}{c}\text { Minimalna odległość } \\
\text { widoczności na krzywolinio- } \\
\text { wym odcinku wlotu [m] }\end{array}$ & $\begin{array}{l}\text { mniejsza } \\
20-120\end{array}$ & $\begin{array}{r}\text { większa } \\
35-180\end{array}$ & Zależy od prędkości miarodajnej \\
\hline $\begin{array}{l}\text { Minimalna zalecana odległość } \\
\text { pomiędzy sąsiednimi skrzyżo- } \\
\text { waniami [m] }\end{array}$ & $\begin{array}{c}\text { mniejsza } \\
300-3000\end{array}$ & $\begin{array}{c}\text { większa } \\
500-5000\end{array}$ & Zależy także od klasy technicznej drogi \\
\hline $\begin{array}{c}\text { Skos załamania w planie krawę- } \\
\text { dzi jezdni drogi na skrzyżowaniu } \\
\text { skanalizowanym }\end{array}$ & $\begin{array}{c}\text { większy } \\
1: 10(1: 5)- \\
1: 20(1: 15) \\
\end{array}$ & $\begin{array}{c}\text { mniejszy } \\
1: 10-1: 40 \\
(1: 30) \\
\end{array}$ & Zależy od prędkości miarodajnej \\
\hline $\begin{array}{l}\text { Maksymalne zalecane pochy- } \\
\text { lenie podłużne wlotów }\end{array}$ & $\begin{array}{l}\text { mniejsze } \\
3 \%-4 \%\end{array}$ & $\begin{array}{l}\text { większe } \\
4 \%-6 \%\end{array}$ & Zależy od klasy technicznej drogi \\
\hline $\begin{array}{c}\text { Przejścia dla pieszych na } \\
\text { skrzyżowaniu z sygnalizacją }\end{array}$ & stosuje się & $\begin{array}{c}\text { stosuje się } \\
\text { w mniejszym } \\
\text { zakresie }\end{array}$ & $\begin{array}{c}\text { Sposób prowadzenia pieszych zależy } \\
\text { od potrzeb ruchu pieszego oraz organi- } \\
\text { zacji ruchu na skrzyżowaniu }\end{array}$ \\
\hline Szerokość przejść dla pieszych & różnie & $\begin{array}{c}\text { różnie, } \\
\text { częściej min. } \\
\text { szerokość } 4 \mathrm{~m}\end{array}$ & $\begin{array}{l}\text { Zależy od natężenia ruchu pieszych, } \\
\text { prędkości pieszych, czasu trwania } \\
\text { cyklu, długości sygnału zielonego }\end{array}$ \\
\hline $\begin{array}{l}\text { Dodatkowe pasy ruchu dla } \\
\text { skrętu w prawo lub w lewo }\end{array}$ & $\begin{array}{c}\text { krótsze } \\
\text { strefy zmiany } \\
\text { pasa ruchu } \\
\text { i zwalniania }\end{array}$ & $\begin{array}{l}\text { dłuższe } \\
\text { strefy zmiany } \\
\text { pasa ruchu } \\
\text { i zwalniania }\end{array}$ & $\begin{array}{c}\text { Oprócz poprawy przepustowości } \\
\text { i bezpieczeństwa stosuje się poza terenem } \\
\text { zabudowy również dla poprawy dostrze- } \\
\text { galności skrzyżowania. Długość zależy } \\
\text { od prędkości miarodajnej i od pochylenia } \\
\text { podłużnego wlotu } \\
\end{array}$ \\
\hline Wyspy typu „,kropla” & nie stosuje się & $\begin{array}{l}\text { stosuje się } \\
\text { na wlotach } \\
\text { podporządk. }\end{array}$ & \multirow{2}{*}{$\begin{array}{c}\text { Zastosowanie, ukształtowanie } \\
\text { i kompozycja zależą od natężeń } \\
\text { i organizacji ruchu oraz geometrii skrzy- } \\
\text { żowania. Inne są funkcje wysp na terenie } \\
\text { zabudowy i poza nim }\end{array}$} \\
\hline Wyspa trójkątna & stosuje się & $\begin{array}{l}\text { stosuje się } \\
\text { częściej }\end{array}$ & \\
\hline Sposób sterowania & różna liczba faz & $\begin{array}{l}\text { zazwyczaj } \\
3 \text { fazowe }\end{array}$ & $\begin{array}{c}\text { Poza terenem zabudowy dominuje } \\
\text { długość fazy na kierunku głównym, } \\
\text { przy braku wzbudzeń obowiązuje } \\
\text { strategia „preference” }\end{array}$ \\
\hline $\begin{array}{l}\text { Wymagany minimalny poziom } \\
\text { swobody ruchu PSR na skrzy- } \\
\text { żowaniu }\end{array}$ & $\begin{array}{l}\text { niższy } \\
\text { PSR III - IV }\end{array}$ & $\begin{array}{c}\text { wyższy } \\
\text { PSR II - III }\end{array}$ & $\begin{array}{l}\text { Zależy od klasy drogi i rodzaju wlotu } \\
\text { (z pierwszeństwem, podporządkowany) }\end{array}$ \\
\hline
\end{tabular}


W latach 2008 - 2012 prowadzone były badania identyfikacyjne na terenie kilku województw w Polsce (40 skrzyżowań zlokalizowanych poza terenem zabudowy oraz 31 miejskich) w celu określenia rzeczywistych różnic rozwiązań miejskich i zamiejskich skrzyżowań z sygnalizacją, mogących wpływać na zachowania uczestników ruchu [8]. Poniżej przedstawiono porównania w zakresie kilku wybranych cech skrzyżowań:

- W zakresie kata przecięcia się osi dróg, na skrzyżowaniach poza terenem zabudowy częściej niż w miastach występują odchyłki większe niż $10^{\circ}$ od kąta prostego.

- Kanalizacja skrzyżowań. Wszystkie analizowane skrzyżowania były skanalizowane, przy czym znacznie częściej kanalizacja dotyczyła wlotów nadrzędnych (rys. 1). Jest to szczególnie ważne w przypadku skrzyżowań zamiejskich z uwagi na dostrzegalność skrzyżowania. W kanalizacji wlotów podporządkowanych dominuje na skrzyżowaniach poza terenem zabudowy wyspa typu kropla (60\% przypadków).

- Dodatkowy pas do skrętu w lewo na wlotach drogi z pierwszeństwem przejazdu występuje równie często na skrzyżowaniach na terenie zabudowy jak i poza nim. Poza terenem zabudowy jeden pas na wlocie podporządkowanym jest typowym rozwiązaniem dla skrzyżowań bez sygnalizacji. Rozwiązanie takie istniejące przed zainstalowaniem sygnalizacji na skrzyżowaniu zazwyczaj pozostaje po jej zainstalowaniu.

- Odcinki składowe dodatkowych pasów. Na skrzyżowaniach zlokalizowanych poza terenem zabudowy, z uwagi na wyższą prędkość miarodajną dłuższy jest

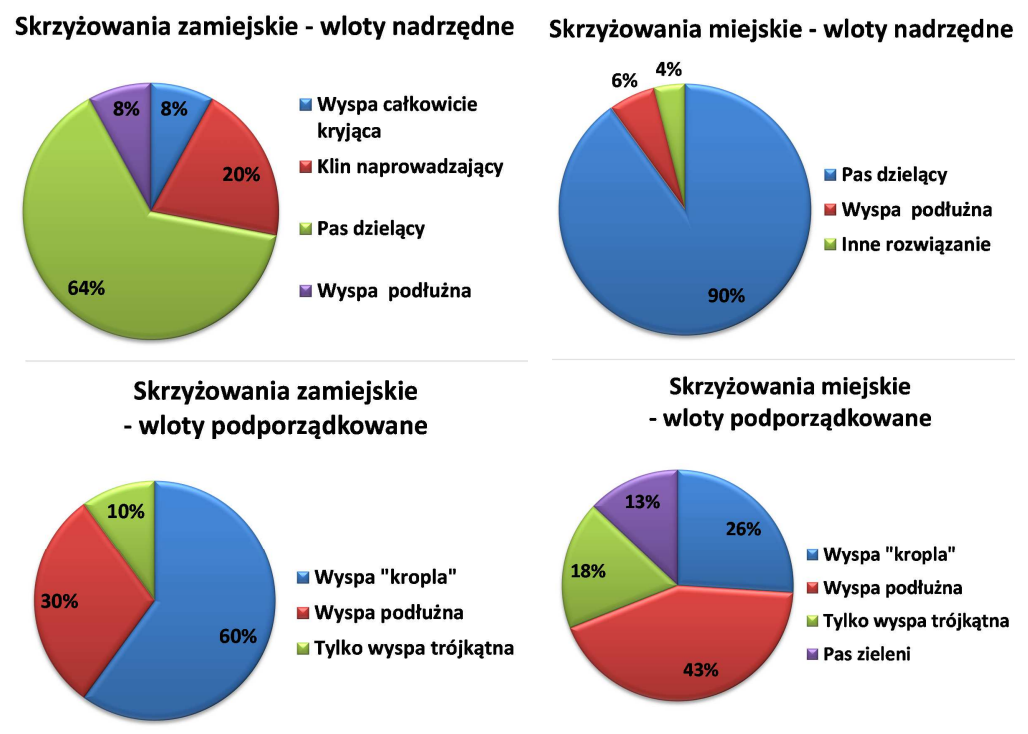

Rys. 1. Udział elementów kanalizujących ruch na wlotach nadrzędnych i podporządkowanych skrzyżowań miejskich i zamiejskich [8]

Fig. 1. Share of elements channelling traffic at main and subordinate entries to urban and rural intersections [8] 
- odcinek zwalniania, a na terenie zabudowy, z uwagi na dłuższe kolejki - odcinek akumulacji.

- Chodniki na wlotach nadrzędnych na skrzyżowaniach poza terenem zabudowy związane są, w większości przypadków z lokalizacją przystanku autobusowego, który zazwyczaj znajduje się na wylotach drogi nadrzędnej.

- Na wlotach nadrzędnych skrzyżowań poza terenem zabudowy dominuje jedno przejście dla pieszych, a na wlotach podporządkowanych równie częsty jest brak przejścia jak i występowanie jednego przejścia.

- Mniejsze powierzchnie skrzyżowań poza terenem zabudowy wynikają głównie z braku rozbudowy wlotów podporządkowanych. Nie występuje na nich natomiast przybliżanie linii zatrzymania związane z brakiem przejść dla pieszych ze względu na zapewnienie dostrzegalności sygnalizatorów.

- Na skrzyżowaniach zamiejskich wymagana jest widoczność na zatrzymanie przed końcem kolejki oraz widoczność sygnalizatora przy dojeździe do skrzyżowania $[20,25]$.

\section{Parametry ruchu drogowego i zachowania uczestników ruchu}

Podstawową charakterystykę ruchu na skrzyżowaniu tworzą przede wszystkim natężenia ruchu, struktura kierunkowa i rodzajowa oraz zmienność w czasie, a ponadto prędkość na dojeździe do skrzyżowania. W badaniach prowadzonych na skrzyżowaniach zamiejskich [8] zidentyfikowano znaczne zróżnicowanie natężenia ruchu. Sumaryczne natężenia na skrzyżowaniach wynosiły od bardzo małego niecałe $500 \mathrm{P} / \mathrm{h}$ do znacznego ok. $3000 \mathrm{P} / \mathrm{h}$. Z uwagi na proporcje obciążenia ruchem badane skrzyżowania można podzielić na dwa typy, pierwszym jest połączenie dróg o dużym natężeniu ruchu na obu kierunkach (rys. 2a), drugim typem jest skrzyżowanie ze znacznym zróżnicowaniem natężeń na obu kierunkach (rys. 2b). W tym drugim przypadku dość częstą jest sytuacja, w której natężenie na wlotach bocznych nie przekracza 10\% ruchu na skrzyżowaniu. Można zaobserwować wyraźne różnice w geometrii skrzyżowań tych dwóch typów pod względem liczby pasów ruchu oraz rodzaju wysp kanalizujących ruch na tarczy skrzyżowania.

Powszechnie stosowaną charakterystyką, opisującą zakres zmienności natężenia ruchu w godzinie, opartą na 15-min. wartościach natężenia, jest wskaźnik nierównomierności ruchu $k_{15}$. Dla analizowanych skrzyżowań wskaźnik ten przyjmował wartości powyżej 0,90, a jego średnia wartość wyniosła 0,95 .W praktycznych analizach, przy braku danych o zmienności ruchu w godzinie, można przyjmować do wyznaczenia natężenia obliczeniowego $\left(Q_{o b l}=Q / k_{15}\right)$ dla skrzyżowań poza terenem zabudowy wartości $k_{15}$ z przedziału $0,92-0,98$ [8].

Udział pojazdów ciężkich $u_{c} \mathrm{~W}$ ruchu na wlotach skrzyżowań zamiejskich wahał się od 7,7\% do 31,0\%. Średnia wartość $u_{c}$ wyniosła ok. 21\%. Znaczne jest zróżnicowanie udziału pojazdów ciężkich na poszczególnych pasach przekrojów dwujezdniowych. Na lewym pasie rzadko $u_{c}$ przekraczało $15 \%$, podczas gdy na pasie prawym przekraczało i $50 \%$. Przeciętnie na pasie lewym $u_{c}$ wynosiło $11,4 \%$ a na pasie prawym $40,1 \%$ [8]. 

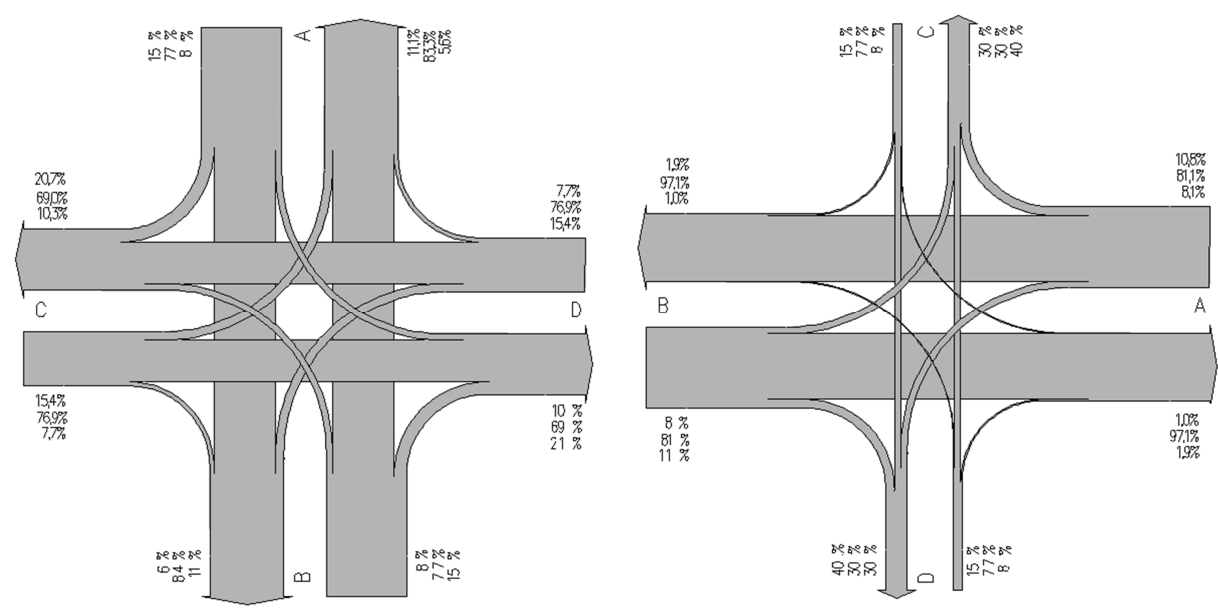

Rys. 2. Proporcje natężeń ruchu na skrzyżowaniu dwóch dróg: a) o dużym obciążeniu ruchem na obu kierunkach, b) o dużym zróżnicowaniu natężeń na obu kierunkach [8]

Fig. 2. Proportions of demand flow at the intersection of two roads: a) heavy traffic in both directions, b) large variations of demand flow between two directions [8]

\section{Sterowanie ruchem}

O celowości zastosowania sygnalizacji na skrzyżowaniu poza terenem zabudowy najczęściej przesądzają względy bezpieczeństwa; rzadziej względy sprawności ruchu. Przeprowadzone analizy dla badanych skrzyżowań [8] wykazały, że mimo nieznacznych natężeń na wlotach bocznych, na skrzyżowaniach z intensywnym ruchem nadrzędnym (zwłaszcza na drodze wielopasowej) instalacja sygnalizacji świetlnej jest zasadna ze względów zarówno bezpieczeństwa, jak i sprawności ruchu. Bez sygnalizacji przejazd przez skrzyżowanie pojazdów z wlotów bocznych wiązałby się z nieakceptowanymi przez kierujących stratami czasu. Na części skrzyżowań, wg przeprowadzonych obliczeń warunki ruchu dla wlotów podporządkowanych określono jako bardzo dobre lub dobre (straty czasu nie przekraczały 15 lub $30 \mathrm{~s} / \mathrm{P}$ ), a stopień wykorzystania przepustowości był nieznaczny (2\% - 40\% [8]). Skrzyżowania te w aspekcie sprawności mogłyby z powodzeniem funkcjonować bez sygnalizacji świetlnej.

Ustalenie programu sygnalizacji - układu faz podstawowych (realizowanych w stanie ciągłych wzbudzeń detektorów) jest złożonym zagadnieniem, którego celem jest zapewnienie przepustowości i akceptowalnych warunków ruchu. Przy wysokich prędkościach na dojeździe do skrzyżowania istotny jest problem konfiguracji systemu detekcji w kontekście bezpieczeństwa jak i warunków ruchu. Na skrzyżowaniach, które objęte były badaniami autorów, w większości przypadków funkcjonowała sygnalizacja z trzema fazami podstawowymi (77\% skrzyżowań), $\mathrm{z}$ dopuszczeniem kolizyjnego przebiegu strumieni $\mathrm{w}$ fazie obsługującej kierunek drugorzędny. Oprócz układu faz podstawowych, stosowane są fazy możliwe, rea- 
lizowane w zależności od zgłoszeń pojazdów na poszczególnych pasach ruchu oraz pieszych na przejściach.

Parametry programu sygnalizacji świetlnej - długości cyklu i sygnałów zielonych ustala się głównie pod kątem zapewnienia odpowiednich warunków ruchu pojazdów. Na skrzyżowaniach zlokalizowanych poza terenem zabudowy istotne jest znalezienie kompromisu między uprzywilejowaniem ruchu w ciągu drogi krajowej, a potrzebami obsługi pieszych przekraczających drogę krajową (wymagają oni często długiego sygnału zielonego) oraz niewydłużenia czasu oczekiwania na sygnał zielony dla pojazdów obsługiwanych w pozostałych fazach ruchu. Program maksymalny przygotowywany jest dla sytuacji, kiedy wystąpią ciągłe zgłoszenia uczestników ruchu na detektorach we wszystkich grupach sygnałowych.

Porównanie obliczeń czasów międzyzielonych na skrzyżowaniach poza terenem zabudowy pokazuje, że metoda obliczeniowa wymagana w Polsce prowadzi do przyjmowania krótszych czasów międzyzielonych niż w USA, Niemczech i Francji [3] (rys. 3). W szczególności zauważalne są różnice w długości sygnału żółtego. Stała, $3 \mathrm{~s}$ długość sygnału żółtego jest niedostosowana do wyższych prędkości pojazdów. Typowe ograniczenie prędkości na dojeździe do skrzyżowania do $70 \mathrm{~km} / \mathrm{h}$ nie gwarantuje bezpiecznego zatrzymania się pojazdu w ciągu $3 \mathrm{~s}$ sygnału żółtego. Prowadzi to do wjazdów podczas sygnału czerwonego na tarczę skrzyżowania. Jak wykazały analizy symulacyjne, uwzględniające występowanie sprzężenia zwrotnego między długością sygnału żółtego a zachowaniem kierujących, wydłużenie sygnału żółtego do $4 \mathrm{~s}$ pozwoliłoby zredukować liczbę wjazdów na skrzyżowanie podczas sygnału czerwonego o 33\% [29, 4]. Dodatkowe instalowanie fotoradarów w pobliżu niebezpiecznych skrzyżowań zamiejskich z sygnalizacją pozwala skutecznie obniżyć prędkości na dojeździe i przy wydłużonym sygnale żółtym zwiększyć kontrolę strefy dylematu, a nawet eliminować jej obecność.

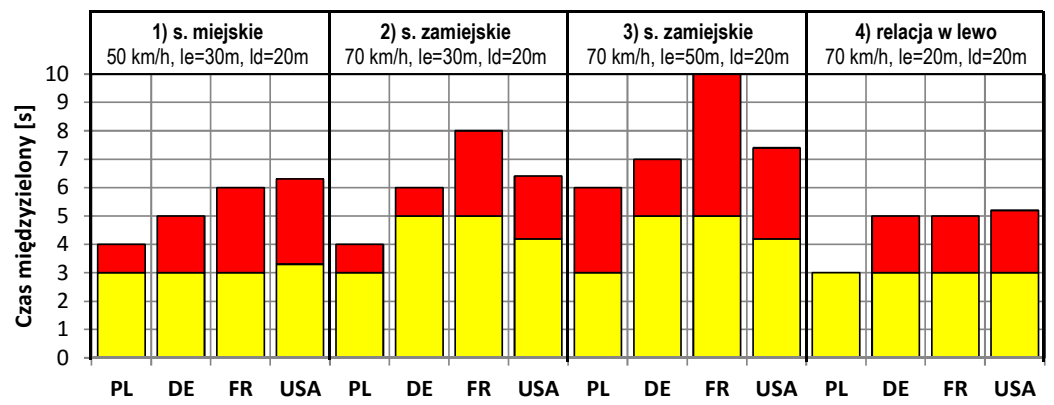

Rys. 3. Porównanie czasów międzyzielonych obliczonych wg wytycznych w różnych krajach, na podstawie [3]

Fig. 3. Comparison of intergreen times calculated according to different countries' guidelines, based on [3] 


\section{Badania natężeń nasycenia bezkolizyjnych relacji}

Podstawowym parametrem rzutującym na przepustowość pasów ruchu na wlotach skrzyżowań z sygnalizacją jest natężenie nasycenia. Według metody polskiej [7] natężenie nasycenia $S$ to maksymalne natężenie strumienia pojazdów, które mogą przejechać linię zatrzymań danego pasa lub obliczeniowej grupy pasów ruchu, przy danych warunkach ruchowych i drogowych w okresie godziny efektywnego sygnału zielonego. Przyjmuje się w warunkach polskich, że wyjściowa wartość natężenia nasycenia relacji bezkolizyjnej na pasie, na którym nie występuje inna relacja kolizyjna wynosi 1900 so/hz, oraz 1700 so/hz jeżeli z pasa korzysta również relacja o kolizyjnym przebiegu. Wartości uznane za wyjściowe są sprowadzane do warunków rzeczywistych po uwzględnieniu szeregu wpływów, w tym szerokości pasa ruchu, promienia skrętu, udziału pojazdów ciężkich, pochylenia podłużnego oraz lokalizacji pasa.

Chwilowa wartość natężenia nasycenia odpowiada maksymalnemu możliwemu odpływowi pojazdów z kolejki na pasie ruchu w czasie sygnału zielonego [10]. Najnowsze badania $[6,8,14]$ wartości wyjściowych natężeń nasycenia odnoszą się do analiz zmienności intensywności odpływu w przedziale środkowym sygnału zielonego par pojazdów osobowych. Natężenie nasycenia w pojedynczym cyklu sygnalizacyjnym wyznaczyć można z ilorazu $3600 / \overline{t_{n s}}$, gdzie $\overline{t_{n s}}$ oznacza średni odstęp nasycenia par pojazdów osobowych (rys. 4).

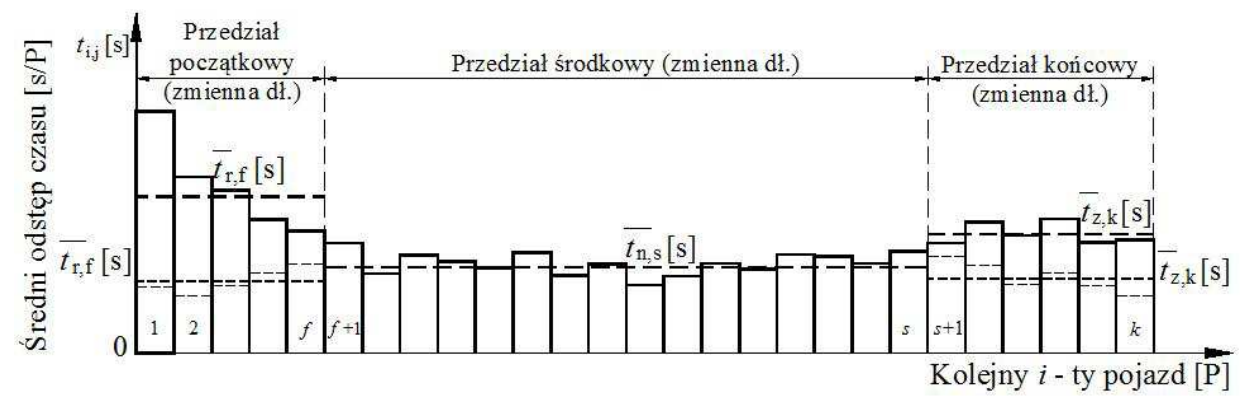

Rys. 4. Modelowy proces obsługi pojazdów w cyklu sygnalizacyjnym [6, 8, 14]

Fig. 4. Service process model during a signal cycle $[6,8,14]$

W pracach $[6,28]$ wprowadzono zmienną liczbę odrzuconych $f$ odstępów między pojazdami w przedziale początkowym sygnału zielonego oraz w przedziale końcowym (rys. 4) z uwzględnieniem warunków pogodowych. Początek i koniec przedziału środkowego ustalony został na podstawie analiz porównawczych sąsiadujących ze sobą odstępów czasu między kolejnymi pojazdami przejeżdżającymi linię zatrzymań $\mathrm{z}$ wykorzystaniem testu parametrycznego $t$-Studenta na poziomie istotności $\alpha=0,05$. Odrzucano od 2 do 8 początkowych odstępów między pojazdami. Badania empiryczne zmienności odstępów czasu między po- 
jazdami i natężeń nasycenia prowadzone były zarówno w miastach $[6,14]$ jak i poza miastami [8]. Badania wykazały, że przeciętne odstępy czasu między pojazdami z kolejki przejeżdżającymi linię zatrzymań są wyraźnie większe na wlotach skrzyżowań zamiejskich, natomiast rozrzut ich wartości chwilowych jest zbliżony na skrzyżowaniach miejskich i zamiejskich.

Przeliczając średnie odstępy między pojazdami na natężenia nasycenia uzyskano stosunkowo niskie ich wartości w niekorzystnych warunkach pogodowych w miastach oraz w korzystnych warunkach pogodowych poza miastami na skrzyżowaniach zlokalizowanych na drogach krajowych. Wartości średnie różnią się od zaleceń podawanych w metodzie polskiej [7], które to głównie odnoszą się do warunków miejskich i przeciętnych warunków atmosferycznych. Zauważono, że:

- dla skrzyżowań miejskich średnia wartość wyjściowa natężenia nasycenia $S_{\mathrm{w}}$ kształtuje się w zakresie od 1670 so/hz przy opadach śniegu i w długotrwałym deszczu do $2170 \mathrm{so} / \mathrm{hz}$ przy korzystnych warunkach pogodowych (pogoda pochmurna i sucha nawierzchnia),

- dla skrzyżowań zamiejskich wartość średnia natężenia nasycenia $S$ wynosi: dla jednego pasa $-1428 \mathrm{so} / \mathrm{hz}$, dla dwóch pasów z relacją na wprost, odpowiednio $1582 \mathrm{so} / \mathrm{hz}$ dla pasa wewnętrznego i 1466 so/hz dla pasa zewnętrznego.

Analizy zmienności natężenia nasycenia przeprowadzone zostały również w miastach poniżej 200 tys. mieszkańców. $Z$ analiz wynika, że w Polsce, podobnie jak w Kanadzie [17], występuje znaczące dla analiz zróżnicowanie wartości wyjściowych natężeń nasycenia. $\mathrm{W}$ badaniach uzyskano znacznie niższą średnią wartość wyjściowego natężenia nasycenia wynoszącą 1750 so/hz niż przyjmowana obecnie w metodzie [7] (1900 so/hz) i występująca w dużych miastach [6, 28]. Poniżej na rys. 5 zestawiono i porównano wartości natężeń nasycenia dla skrzyżowań miejskich i zamiejskich.
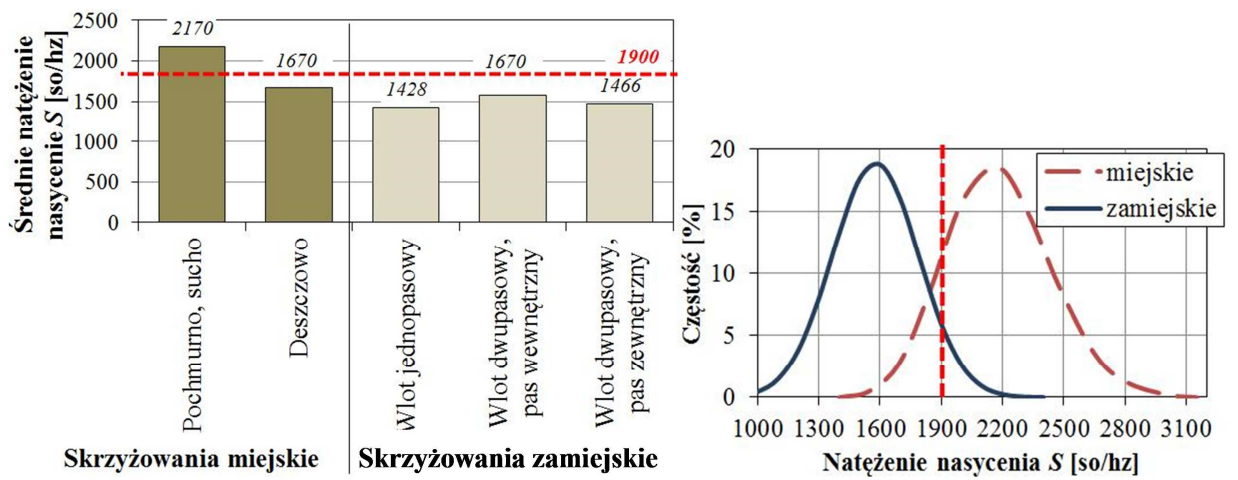

Rys. 5. Porównanie empirycznych wartości natężeń nasycenia wyznaczonych dla warunków miejskich i zamiejskich, dla wlotów z jednym i dwoma pasami z relacją na wprost $[6,8]$

Fig. 5. Comparison of empirical values of saturation flows determined for urban and rural conditions at entries with one and two lanes for through traffic $[6,8]$ 
Niższe wartości natężeń nasycenia relacji na wprost na pasach ruchu skrzyżowań zamiejskich spowodowane są mniej agresywną jazdą kierujących pojazdami i utrzymywaniem większych odstępów miedzy pojazdami oraz znacznie mniejszą gęstością skrzyżowań. Rozrzut chwilowych wartości natężenia nasycenia jest podobny na skrzyżowaniach w obu rozważanych lokalizacjach. Powoduje on, podobnie jak i wahania natężenia dopływu, zmienne warunki ruchu w kolejnych cyklach sygnalizacyjnych.

\section{Modele matematyczne wyjściowych wartości natężeń nasycenia}

W metodzie polskiej [7] oraz innych metodach zagranicznych [2, 11, 12, 17] bazuje się na stałej wartości wyjściowej natężenia nasycenia, która następnie dostosowywana jest do warunków lokalnych poprzez wprowadzenie współczynników korygujących. Z powyższych analiz wynika, że wyjściowa wartość natężenia nie jest stała, a jej zmienność ma charakter deterministyczny i losowy. Modele matematyczne natężeń nasycenia bazujące na wynikach analiz empirycznych można odnaleźć również w pracy [18] dla miast o różnej wielkości. Poniżej w tablicy 2 zestawiono własne modele dla skrzyżowań miejskich i zamiejskich.

Tabela 2. Modele regresyjne natężeń nasycenia $S$ (so/hz) pasów ruchu z relacją na wprost $[8,15]$

Table 2. Regression models for basic saturation flow $S$ (pcu/h) in through traffic lanes $[8,15]$

\begin{tabular}{|c|c|c|c|}
\hline Lp. & $f_{4}[\%]$ & Skrzyżowania miejskie & Dla \\
\hline $\begin{array}{c}1 \\
\text { pas }\end{array}$ & $\leq 10 \%$ & $1689+82 \cdot f_{1}+5 \cdot f_{2}-175 \cdot \delta_{2}-243 \cdot \delta_{4}$ & - \\
\hline \multirow{2}{*}{$\begin{array}{c}2 \\
\text { pasy }\end{array}$} & $\leq 10 \%$ & $1249+91 \cdot f_{1}+20 \cdot f_{2}-138 \cdot \delta_{2}+85 \cdot \delta_{7}$ & - \\
\hline & $\begin{array}{l}\leq 10 \%(\text { pas L }) \\
>10 \%(\text { pas } \mathrm{P})\end{array}$ & $1810+68 \cdot f_{1}+2 \cdot f_{3}-502 \cdot f_{4}-113 \cdot \delta_{2}-213 \cdot \delta_{3}$ & - \\
\hline $\begin{array}{c}3 \\
\text { pasy }\end{array}$ & $\begin{array}{l}\leq 10 \%(\text { pas } \mathrm{L}) \\
\leq 10 \%(\text { pas } \mathrm{S}) \\
\leq 10 \%(\text { pas } \mathrm{P})\end{array}$ & $1577+83 \cdot f_{1}+9 \cdot f_{3}-196 \cdot \delta_{2}-73 \cdot \delta_{1}-84 \cdot \delta_{5}+165 \cdot \delta_{8}$ & - \\
\hline Lp. & $f_{4}[\%]$ & Skrzyżowania zamiejskie & Dla \\
\hline $\begin{array}{c}1 \\
\text { pas }\end{array}$ & - & $\begin{array}{r}1258.98-0.74 \cdot G \cdot \delta_{9}+159.63 \cdot f_{1}-222.44 \cdot f_{4} \cdot f_{5} \\
1482.32-1.08 \cdot G \cdot \delta_{9}+144.53 \cdot f_{1}-126.38 \cdot f_{4} \cdot f_{5}\end{array}$ & $\begin{array}{l}f_{5}>0, f_{1}>0 \\
f_{5}<0, f_{1}>0\end{array}$ \\
\hline \multirow{3}{*}{$\begin{array}{c}2 \\
\text { pasy }\end{array}$} & $<10$ & $\begin{array}{l}1211.77+61.67 \cdot f_{1}+83.55 \cdot \delta_{7} \\
1700.62+49.16 \cdot f_{1}+49.42 \cdot \delta_{7} \\
\end{array}$ & $\begin{array}{c}1 * \\
2 \& 3^{*}\end{array}$ \\
\hline & $10 \div 25$ & $\begin{array}{c}1440.75+198.95 \cdot \delta_{7}-1001.84 \cdot f_{4} \cdot f_{5} \\
1812.46+123.06 \cdot f_{1}+220.25 \cdot \delta_{7}-1666.63 \cdot f_{4} \cdot f_{5}\end{array}$ & $\begin{array}{c}1 *, f_{5}>0 \\
2 \& 3^{*}, f_{5}>0\end{array}$ \\
\hline & $\geq 25$ & $\begin{array}{l}1237.09+164.57 \cdot f_{1}-117.16 \cdot f_{4} \cdot f_{5} \\
1563.62+139.92 \cdot f_{1}-765.86 \cdot f_{4} \cdot f_{5}\end{array}$ & $\begin{array}{l}f_{5}>0 \\
f_{5}<0\end{array}$ \\
\hline
\end{tabular}

Oznaczenia użyte w tabeli 2: $f_{1}$ - czas tracony w przedziale początkowym, $f_{2}-$ kolejka pojazdów na początku sygnału zielonego, $f_{3}$ - natężenie dopływające, $f_{4}$ - udział pojazdów ciężkich w ruchu. $\delta_{\mathrm{i}}(0$ lub 1): $\delta_{1}$ - obecność deszczu krótkotrwałego, $\delta_{2}-$ długotrwałego oraz $\delta_{3}-$ śniegu, $\delta_{4}$ - mała powierzchnia skrzyżowania $<1200 \mathrm{~m}^{2}, \delta_{5}$ - średnia $\left(1200 \mathrm{~m}^{2} ; 2400 \mathrm{~m}^{2}>, \delta_{6}-\right.$ duża $>2400 \mathrm{~m}^{2}, \delta_{7}-$ pas wewnętrzny, $\delta_{8}$ - szczyt popołudniowy, *stopień zurbanizowania otoczenia skrzyżowania [8] 
Z przeprowadzonych analiz wynika, że na wartość natężenia nasycenia w sposób znaczący mają wpływ: czas tracony w przedziale początkowym $f_{1}$, długość sygnału zielonego $G$, występowanie cykli nasyconych $\delta_{9}$, pochylenie podłużne $f_{5}$, położenie pasa ruchu $\delta_{7}$ oraz ,ukryty” (nieujęty we współczynniku ekwiwalentnym) udział pojazdów ciężkich w ruchu $f_{4}$. Generalnie im większy jest udział pojazdów ciężkich $w$ ruchu, tym wartości średnie natężeń nasycenia przyjmują mniejsze wartości. Dla powyższych modeli regresji wielorakiej, segmentowej uzyskano wysokie współczynniki determinacji $R^{2}$, tj. od 0,68 do 0,86 . Poszczególne modele predykcji natężenia nasycenia podzielono również względem pochylenia podłużnego ( $i<0$ lub $i>0$ ) oraz stopni zurbanizowania (1 lub 2 i 3). Zaobserwowano, że przy większych odstępach, w jakich przejeżdżają linię zatrzymań pojazdy z kolejki (m.in. wloty skrzyżowań zamiejskich, niekorzystne warunki pogodowe) liczba odrzucanych początkowych odstępów przy wyznaczaniu natężenia nasycenia będzie mniejsza. Średni czas tracony w fazie sygnalizacyjnej przyjmuje zbliżone wartości, ale rozrzut czasu traconego jest znacznie większy w korzystnych warunkach pogodowych niż w niekorzystnych oraz dla skrzyżowań zamiejskich. Ustalenia mogą być wykorzystywane przy prowadzeniu badań natężenia nasycenia, poprzez racjonalne określanie środkowego, nasyconego przedziału sygnału zielonego.

\section{Wpływ natężeń nasycenia na warunki ruchu na miejskich i zamiejskich skrzyżowaniach z sygnalizacją}

Natężenie nasycenia stanowi punkt wyjścia przy doborze parametrów sterowania i obliczeń przepustowości pasa lub grupy pasów ruchu [7]. Niewłaściwe ustalenie natężenia nasycenia powoduje, szczególnie w przypadku natężeń ruchu bliskich lub większych od przepustowości grup analizowanych pasów, znaczne niedoszacowanie strat czasu pojazdów (rys. 6). W celu pokazania zależności średnich strat czasu od natężeń nasycenia przeprowadzono badania symulacyjne [14] przy ustalonym natężeniu potoku dopływającego i zmiennym natężeniu nasycenia oraz przy różnych parametrach sterowania. Przyjęto, że wartość natężenia potoku dopływającego wynika z założenia, że dla natężenia nasycenia $S=1800 \mathrm{so} / \mathrm{hz}$ natężenie potoku dopływającego zbliżone będzie do przepustowości pasa ruchu ( $X$ $=Q / C \approx 1,0)$. Wyróżniono pięć przeciętnych wartości natężeń nasycenia $S$ [so/hz]: 1400, 1600, 1800, 2000 i 2200. Przyjęte wartości wynikają z empirycznie ustalonego zakresu zmienności natężeń nasycenia i obrazują wpływ warunków pogodowych oraz lokalizacji skrzyżowania. W przypadku natężeń nasycenia odpowiadających standardowym wartościom, straty czasu pojazdów nie przekraczają zdefiniowanych w [7] akceptowanych poziomów swobody ruchu. W sytuacji, gdyby skrzyżowanie dla tych samych warunków ruchowych byłoby zlokalizowane poza terenem zabudowy, straty czasu wzrosłyby wielokrotnie z uwagi na przekroczenie przepustowości (rys. 6). 


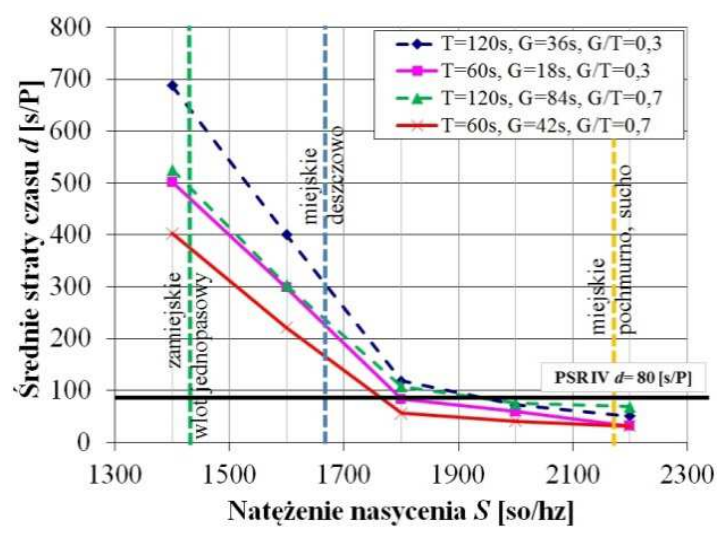

Rys. 6. Związek między średnią stratą czasu i natężeniem nasycenia dla wybranych parametrów sterowania $(G / T=0.3$ i $0.7, T=60 \mathrm{~s}$ i $120 \mathrm{~s})[6,8]$

Fig. 6. Relationship between average delay and saturation flow for selected control parameters $(G / T=0.3$ and $0.7, T=60 \mathrm{~s}$ and $120 \mathrm{~s})[6,8]$

Natężenia nasycenia w kolejnych cyklach są zmienną losową (liczba pojazdów, która może być obsłużona na sygnale zielonym w danym cyklu podlega wyraźnym wahaniom). Właściwe odwzorowanie niedeterministycznego charakteru rozładowania kolejek na wlotach skrzyżowania z sygnalizacją umożliwia ocenę skrzyżowania $\mathrm{w}$ aspekcie niezawodnościowym (utraty i możliwego odzyskania sprawności). Badania i analizy w tematyce wiążącej niezawodność z przepustowością i analizami warunków ruchu przedstawione zostały w pracach [13, 15, 16, 28].

\section{Podsumowanie}

Przeprowadzone badania wykazały, że skrzyżowania z sygnalizacją zlokalizowane na drogach $\mathrm{z}$ wysokimi prędkościami (poza obszarami zabudowy oraz w arteriach wlotowych dużych miast) cechuje specyfika zarówno w zakresie geometrii, organizacji ruchu jak i zachowań uczestników ruchu. Częściej niż w warunkach miejskich elementy geometryczne skrzyżowań, jak np. dodatkowe pasy ruchu i kanalizacja, wiążą się z funkcją drogi, dostrzegalnością skrzyżowania, płynnością i bezpieczeństwem ruchu niż z potrzebami ruchowymi. Instalacja sygnalizacji wynika z bardzo długich czasów oczekiwania pojazdów z dróg bocznych (powodowanych przez wysoką prędkość i duże natężenie potoku nadrzędnego), a w efekcie nierzadko wymuszeń i wypadków. Jak wynika z wykonanych analiz, na zdecydowanej większości skrzyżowań udział natężeń ruchu na wlotach głównych jest znacznie większy niż na wlotach podporządkowanych (sięga nawet 90\%). Rozkład ruchu na pasy w przypadku przekrojów wielopasowych determinowany jest innymi względami niż w warunkach miejskich i wymaga szczególnego uwzględnienia struktury rodzajowej ruchu. Program sygnalizacji zwykle jest ustalany z wyraźną preferencją kierunku głównego, co przy potrzebie obsługi 
ruchu pieszego wymaga stosowania długich cykli ( $T \geq 100 \mathrm{~s}$, najczęściej $120 \mathrm{~s}$ ). System detekcji na skrzyżowaniach poza terenem zabudowy ma zazwyczaj większy zasięg (o 30 do $60 \mathrm{~m}$ ) niż w przypadku miast, nie znaleziono jednak przesłanek wiążących dany typ stosowanego układu detektorów z innymi czynnikami geometryczno-ruchowymi skrzyżowania.

$\mathrm{Z}$ przeprowadzonych badań wynika, że występują znaczące różnice w funkcjonowaniu skrzyżowań zamiejskich, istotne $\mathrm{z}$ punktu widzenia potrzeb analiz warunków ruchu i przepustowości. Projektowanie skrzyżowań zamiejskich przy natężeniach nasycenia przyjmowanych dla dużych miast, w sytuacji gdy na wlotach skrzyżowań natężenie ruchu będzie zbliżone do przepustowości powodować będzie powstawania przeciążeń ruchowych. Średnie wartości natężeń nasycenia dla lokalizacji zamiejskich są niższe o ok. 20 - $30 \%$ od lokalizacji miejskich, co przekłada się na znacznie niższe wartości przepustowości, wzrost strat czasu i kolejek oraz występowanie stanów kongestii przy podobnym poziomie natężeń ruchu.

Biorąc pod uwagę nakreśloną w artykule specyfikę skrzyżowań z sygnalizacją zlokalizowanych poza terenem zabudowy, a ponadto stwierdzone znaczne różnice w natężeniach nasycenia, stanowiących podstawę obliczeń przepustowości, racjonalne byłoby podjęcie szeroko zakrojonych prac umożliwiających aktualizację i uzupełnienie obecnych wytycznych projektowania skrzyżowań i rozporządzeń dotyczących sygnalizacji świetlnej na skrzyżowaniach.

\section{Literatura}

[1] A Policy on Geometric Design of Highways and Streets, 5 edition. American Association of State Highway and Transportation Officials, Washington, D.C. 2004.

[2] Akçelik R.: Traffic signals - capacity and timing analysis. Australian Road Research Board, Research Report 123, 1989.

[3] Bąk R.: Sposoby obliczania czasów międzyzielonych na skrzyżowaniach zamiejskich. Technika Transportu Szynowego, nr 9 na CD, 2012.

[4] Bonneson J., Zimmerman K., Brewer M.: Engineering countermeasures to reduce red light running, Federal Highway Administration, Report No. FHWA/TX-03/4027-2, Washington, D.C. 2002.

[5] Chodur J.: Charakterystyka natężeń ruchu na zamiejskich skrzyżowaniach z sygnalizacją. Technika Transportu Szynowego, nr 9, s. 4629-4638 na CD, 2012.

[6] Chodur J., Ostrowski K., Tracz M.: Impact of saturation flow changes on performance of traffic lanes at signalized intersections. Proc. of the 6th International Symposium on Highway Capacity and Quality of Service, Procedia-Social and Behavioral Sciences, Elsevier Vol 16: 600 - 611. Stockholm 2011.

[7] Chodur J., Tracz M., Gaca S., Gondek S., Kieć M, Ostrowski K.: Metoda obliczania przepustowości skrzyżowań z sygnalizacją świetlną. GDDKiA, Warszawa 2004.

[8] Chodur J., Tracz M., Gondek S., Ostrowski K., Bąk R.: Problemy eksploatacyjne skrzyżowań z sygnalizacją świetlną na zamiejskich drogach z dużymi prędkościami. Projekt Badawczy Własny NCN nr N N509 254037, Kraków 2012. 
[9] Dixon K., Kopper N., Schalkwyk I.: Evaluating safety and operations of high-speed intersections, Oregon State University, Corvallis 2010.

[10] Gaca S., Suchorzewski W., Tracz M.: Inżynieria ruchu drogowego. WKiŁ, Warszawa 2008.

[11] HBS 2015. Handbuch für die Bemessung von Straßenverkehrsanlagen. Forschungsgesellschaft für Straßen- und Verkehrswesen e.V., Köln.

[12] Highway Capacity Manual 2010. TRB. Washington D.C., USA.

[13] Ostrowski K.: Attempt to apply the theory of reliability to assessment of signalised lane operation. Proc. of European Safety and Reliability Conference ESREL, Safety and Reliability, Methodology and applications, CRC Press/Balkena, Taylor and Francis Group, p. 335-341, Wrocław 2014.

[14] Ostrowski K.: Zmienność natężeń dopływających do skrzyżowania z sygnalizacją w analizach niezawodności ich funkcjonowania, Prace naukowe Politechniki Warszawskiej, Transport z. 95: Inteligentne Systemy Transportowe i Sterowanie Ruchem w Transporcie, s. 391-400, Warsaw 2013.

[15] Ostrowski K., Chodur J.: Performance and reliability of signalised intersections. Road and Transportation Engineering, Edytor Gaca S., Seria Inżynieria Lądowa, Monografia 483, Politechnika Krakowska, Kraków 2015, s. 33 - 50.

[16] Ostrowski, K., Tracz, M.: Availability and reliability of a signalised lane. Proc. of the 6th International Symposium on Transportation Network Reliability, Japan 2015.

[17] Teply S.: Canadian capacity guide for signalized intersections, The Institute of Transportation Engineers, Canada 2008.

[18] Perez-Cartagena R.I., Tarko A.P.: Calibration of capacity parameters for signalized intersections in Indiana, TRB 2005.

[19] Ray B et All.: NCHRP Report 613: Guidelines for Selection of Speed Reduction Treatments at High-Speed Intersections, Transportation Research Board, Washington D.C. 2008.

[20] Rozporządzenie Ministra Infrastruktury z dnia 3 lipca 2003 roku w sprawie szczegółowych warunków technicznych dla znaków i sygnałów drogowych oraz urządzeń bezpieczeństwa ruchu drogowego i warunków ich umieszczania na drogach. Dz. U. nr 220, poz. 2181 z dnia 23 grudnia 2003 r. oraz późniejsze zmiany: Dz. U. nr 67, poz. 413 z 2008 r. i Dz. U. nr 126, poz. 813 z 2008.

[21] Rozporządzenie Ministra Transportu i Gospodarki Morskiej z dnia 2 marca 1999 roku w sprawie warunków technicznych, jakim powinny odpowiadać drogi publiczne i ich usytuowanie. Dz. U. nr 43, poz. 430 z dnia 2 marca 1999 r.

[22] Richtlinien für die Anlage von Landstraßen. Forschungsgesellschaft für Straßen- und Verkehrswesen Verlag, Köln 2012.

[23] Richtlinien für die Anlage von Stadtstraßen. Forschungsgesellschaft für Straßen- und Verkehrswesen Verlag, Köln 2006.

[24] Richtlinien für Lichtsignalanlagen - RiLSA. Forschungsgesellschaft für Straßen- und Verkehrswesen Verlag, Köln 2010.

[25] The Geometric Layout of Signal-Controlled Junctions and Signalised Roundabouts. Design Manual for Roads and Bridges, Volume 6 Road Geometry, Section 2 Junctions, 
The Highways Agency, Scottish Executive, Welsh Assembly Government, The Department For Regional Development Northern Ireland, TD 50/04,2004.

[26] Traffic Signal Design Guide \& Timing Manual. Alabama Department of Transportation, Alabama 2007.

[27] Tracz M., Chodur J., Gaca S. i inni: Wytyczne projektowania skrzyżowań drogowych, Część I: Skrzyżowania zwykłe i skanalizowane. GDDP, Warszawa 2001.

[28] Tracz, M., Ostrowski, K.: Impact of capacity variability in different weather conditions on reliability of signalised intersections. Proc. of the 5th International Symposium on Transportation Network Reliability: 901-916, Hong Kong 2012.

[29] Van der Horst A.R.A., Wilink A.: Drivers' Decision-Making at Signalized Intersections: An Optimization of the Yellow Timing, Traffic Engineering and Control, 27 (12), p. $615 \div 622,1986$.

\section{STUDY OF THE CHARACTERISTICS AND PERFORMANCE OF SIGNALISED INTERSECTIONS}

\section{S u m m a r y}

A study of urban and rural signalised intersections revealed the specificity of their shape, saturation, and, to a certain extent, also of the control and functioning of urban and rural intersections. Urban signalised intersections have many distinguishing features, both in terms of geometry and traffic management and control. It is caused by higher speed limits, the specificity of traffic characteristics and the development of road surroundings. Identification tests facilitated specifying the set of their characteristics. Headway analysis at the stop line between queued vehicles (passenger cars) allowed determining saturation flows in each signal cycle. Their variability was characterised statistically and differences between urban and rural intersections were determined. Saturation flows at entries to rural intersection are much lower than at urban intersections, which results in their much worse performance in similar traffic volumes relative to urban intersections. The study shows the impact on saturation flows of the number and location of lanes for through traffic and the intensity of the development of the surroundings of rural intersections. The authors developed regression models estimating saturation flows. The results of the study indicate that there exists a need to carry out work enabling an update and supplementation of current guidelines for the design of intersections and regulations governing traffic signals at intersections and verification of analysis methods of capacity and traffic performance at signalised intersections.

Keywords: signalised intersection, intersection characteristics, intersection efficiency

Przestano do redakcji: $07.06 .2016 r$.

Przyjęto do druku: 30.06.2016 r.

DOI: $10.7862 / \mathrm{rb} .2016 .73$ 